\title{
Changes of Plasma Renin Activity Following Intracerebroventricular Administration of Biologically Active Peptides in Two-Kidney, One Clip Hypertensive Rats
}

\author{
Takeru Iwata, M.D., Kunio Hiwada, M.D., \\ and Tatsuo Kokubu, M.D.
}

\section{SUMMARY}

We studied the effects of intracerebroventricular (ICV) administration of angiotensin II (ANG II), bradykinin (BK), leucineenkephalin (Leu-ENK) and neurotensin (NT) on plasma renin activity (PRA), blood pressure and heart rate in acute (less than 4 weeks) and chronic (more than 12 weeks) two-kidney, one clip (2K-1G) hypertensive rats. These four peptides all produced pressor responses. The pressor responses caused by ICV injection of ANG II, BK, Leu-ENK and NT in hypertensive rats did not differ significantly from the response in normal rats. In both acute and chronic $2 \mathrm{~K}-1 \mathrm{C}$ hypertensive rats, ANG II and $\mathrm{BK}$ significantly suppressed PRA, NT did not affect PRA, and Leu-ENK produced a significant increase in PRA followed by a significant decrease in PRA. As compared to normal rats, suppression of PRA by ANG II and NT was attenuated or abolished but BK and Leu-ENK produced significant reductions in PRA in $2 \mathrm{~K}-1 \mathrm{C}$ hypertensive rats. The results indicate that the effects of these four centrally administered peptides on blood pressure, heart rate and PRA in acute and chronic $2 \mathrm{~K}-1 \mathrm{C}$ hypertensive rats were not essentially different from those in normal rats.

\section{Additional Indexing Words:}

Angiotensin II Bradykinin Leucine-enkephalin Neurotensin

7 HE role of the central nervous system in hemodynamic regulation is 1 complex. Recently, a number of biologically active peptides such as angiotensin, kinins, enkephalins and neurotensin, have been demonstrated

\footnotetext{
From the Second Department of Internal Medicine, Ehime University School of Medicine, Ehime, Japan.

Address for reprint: Tatsuó Kokubu, M.D., Second Department of Internal Medicine, Ehime University School of Medicine, Shigenobu-cho, Onsen-gun, Ehime 791-02, Japan.

Received for publication November 21, 1984.
} 
to be present in the brain. ${ }^{1-4)}$ These peptides in the brain are involved in blood pressure control. ${ }^{6}$ Central peptidergic stimulation is important for the elevation and maintenance of high blood pressure in experimental animals. ${ }^{6)}$ Although the renin-angiotensin system plays a primary pathogenic role in two-kidney, one clip $(2 \mathrm{~K}-1 \mathrm{C})$ hypertension in rats, ${ }^{7}$ the central nervous system has been shown to be involved in the development and maintenance of $2 \mathrm{~K}-1 \mathrm{G}$ hypertension. ${ }^{8)-13}$ ) On the other hand, the central mechanism of renin release has been suggested from the results of electrical stimulation of the central nervous system. ${ }^{14), 15)} \mathrm{We}^{16)}$ and the other investigators ${ }^{17)-20)}$ have reported that central peptidergic stimulation influences PRA and blood pressure in normal rats.

In this report, we studied the effects of ICV injection of ANG II, BK, Leu-ENK and NT on PRA, blood pressure and heart rate in acute and chronic $2 \mathrm{~K}-1 \mathrm{C}$ hypcrtensive rats with elevated PRA.

\section{Materials and Methods}

Male Wistar rats weighing 350-500 Gm at the time of the ICV experiment were used. Rats were divided into 3 groups: (1) normal rats, (2) $2 \mathrm{~K}$ $1 \mathrm{C}$ hypertensive rats in the acute phase and (3) $2 \mathrm{~K}-1 \mathrm{C}$ hypertensive rats in the chronic phase.

Surgical procedures for the preparation of the hypertensive rats were as follows. Under pentobarbital anesthesia $(50 \mathrm{mg} / \mathrm{Kg}$, i.p. ), the left kidney was exposed via a flank incision and a silver clip having an internal diameter of $0.21 \mathrm{~mm}$ was placed on the left renal artery. The right kidney was left untouched. Rats were maintained in a room at constant temperature $24 \pm$ $1{ }^{\circ} \mathrm{C}$ ) and humidity $(60 \pm 10 \%)$ with a daily light cycle of 12 hours. Tap water and a rat diet containing $11 \mathrm{mEq}$ of sodium and $19 \mathrm{mEq}$ of potassium per $100 \mathrm{Gm}$ were offered ad libitum. Indirect blood pressure measurements were carried out by the tail-cuff method. ${ }^{21}$ Rats with systolic blood pressures in excess of $160 \mathrm{mmHg}$ were used in the ICV experiment within 4 weeks (acute phase) or after 12 weeks (chronic phase) of the renal artery stenosis.

Three days before the ICV experiment, a stainless steel cannula was stereotaxically implanted into the lateral cerebral ventricle and a polyethylene catheter was placed in the femoral artery under pentobarbital anesthesia as described previously. ${ }^{16)}$

The ICV experiment was performed in conscious and unrestrained rats as described previously. ${ }^{16)}$ Four biologically active peptides (purchased from Protein Research Foundation, Osaka, Japan), ANG II, BK, Leu-ENK and NT were dissolved in an artificial cerebrospinal fluid and $5 \mu \mathrm{l}$ of each 
peptide solution were administered into the lateral cerebral ventricle of the rat. Injection doses of the peptides were as follows: ANG II, $10 \mathrm{ng}$; BK, $1 \mu \mathrm{g}$; Leu-ENK, $100 \mu \mathrm{g}$; NT, $10 \mu \mathrm{g}$. Five $\mu \mathrm{l}$ of artificial cerebrospinal fluid were injected intracerebroventricularly as a control. Blood samples for plasma renin assay were collected 15 and $5 \mathrm{~min}$ before ICV injection and 5,15 and $30 \mathrm{~min}$ after the injection. PRA was measured by radioimmunological microassay. ${ }^{22)}$ The mean value of PRA at 15 and $5 \mathrm{~min}$ before ICV injection was used as the pretreatment value.

Results were expressed as means \pm SEM. Statistical analyses were performed by means of analysis of variance with subsequent Tukey's test for comparison between groups and paired t-test for comparison within groups.

\section{Results}

Pretreatment values of PRA, blood pressure and heart rate

PRA, mean blood pressure (MBP) and heart rate of the 3 groups before ICV injection of the peptides are shown in Table I. 2K-1C hypertensive rats in acute and chronic phases showed significantly elevated PRA compared with the normal rats. PRA in chronic $2 \mathrm{~K}-1 \mathrm{C}$ hypertensive rats was slightly lower than that in acute phase, but the difference was not significant. MBP in $2 \mathrm{~K}-1 \mathrm{C}$ hypertensive rats was significantly higher than that in normal rats. There was a significant difference in MBP between acute $2 \mathrm{~K}-1 \mathrm{C}$ hypertensive rats and chronic ones. Heart rate in acute $2 \mathrm{~K}-1 \mathrm{C}$ hypertensive rats was significantly faster than those in normal rats and chronic $2 \mathrm{~K}-1 \mathrm{C}$ hypertensive rats.

\section{Plasma renin activity after ICV injection}

ICV injection of artificial cerebrospinal fluid showed no significant change in PRA in any of the 3 groups. ICV injection of ANG II reduced

Table I. Plasma Renin Activity, Mean Blood Pressure and Heart Rate before Intracerebroventricular Injection

\begin{tabular}{l|c|c|c}
\hline \multicolumn{1}{c|}{ Groups } & $\begin{array}{c}\text { PRA } \\
\text { (ng ANG I/ml/h) }\end{array}$ & MBP (mmHg) & $\begin{array}{c}\text { Heart rate } \\
\text { (beats/min) }\end{array}$ \\
\hline normal rats & $41.5 \pm 1.8$ & $103.5 \pm 1.4$ & $357 \pm 7$ \\
acute 2K-1C rats & $117.7 \pm 10.7^{*}$ & $163.5 \pm 2.3 * \dagger$ & $378 \pm 6^{*}+$ \\
chronic 2K-1C rats & $100.4 \pm 6.9^{*}$ & $174.6 \pm 2.3^{*}$ & $361 \pm 5$ \\
$* \mathrm{p}<0.05$ compared with normal rats. & \\
$\dagger \mathrm{p}<0.05$ compared with chronic 2K-1C hypertensive rats. \\
$\mathrm{n}=30$ for cach group.
\end{tabular}



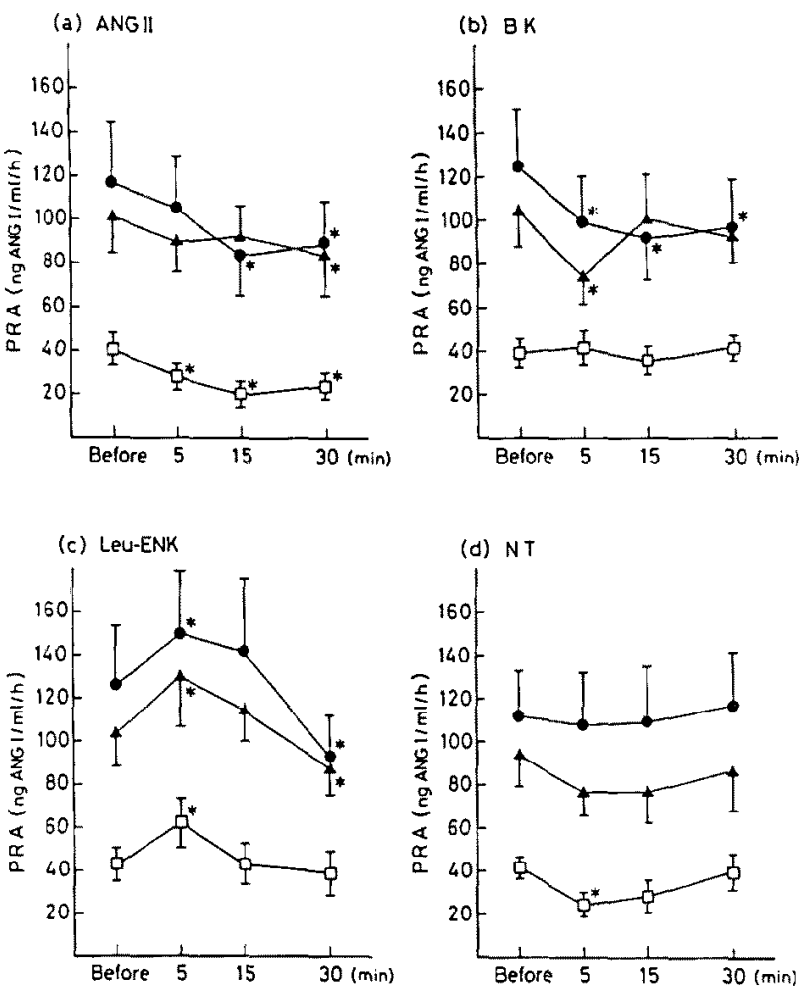

Fig. 1. Changes in PRA after ICV injections of angiotensin II (a), bradykinin (b), leucine-enkephalin (c) and neurotensin (d) in normal rats $(\square)$, acute ( $(\mathbf{O})$ and chronic $(\boldsymbol{\Delta}) 2 \mathrm{~K}-1 \mathrm{C}$ hypertensive rats. Values are means $\pm S E M, n=6$ for all points. Asterisks indicate significant differences from pretreatment values $(p<0,05)$.

PRA in all 3 groups. Significant reductions of PRA were observed at 5, 15 and $30 \mathrm{~min}$ after ICV injection in normal rats, at 15 and $30 \mathrm{~min}$ in acute $2 \mathrm{~K}-1 \mathrm{C}$ hypertensive rats and at $30 \mathrm{~min}$ in chronic hypertensive rats. At $30 \mathrm{~min}$ after ICV injection of ANG II, PRA values of normal rats, acute and chronic $2 \mathrm{~K}-1 \mathrm{C}$ hypertensive rats were $62.2 \pm 7.8 \%, 77.2 \pm 6.3 \%$ and $82.4 \pm$ $7.5 \%$ of the pretreatment value, respectively. The reduction of PRA in $2 \mathrm{~K}-1 \mathrm{C}$ hypertensive rats was attenuated compared with that in normal rats. In 2K-1C hypertensive rats, PRA was less reduced in the chronic phase than in the acute phase.

After ICV injection of BK, PRA showed no significant change in normal rats. In 2K-1G hypertensive rats, however, ICV injection of $\mathrm{BK}$ produced a significant decrease in PRA. In the acute phase, significant reductions in PRA were observed at 5, 15 and $30 \mathrm{~min}$ after the injection and PRA values were $83.9 \pm 3.3 \%, 76.8 \pm 4.0 \%$ and $78.5 \pm 5.2 \%$ of the pretreatment value, respectively. In the chronic phase, significant reduction in $\mathrm{PRA}$ was ob- 
(a)

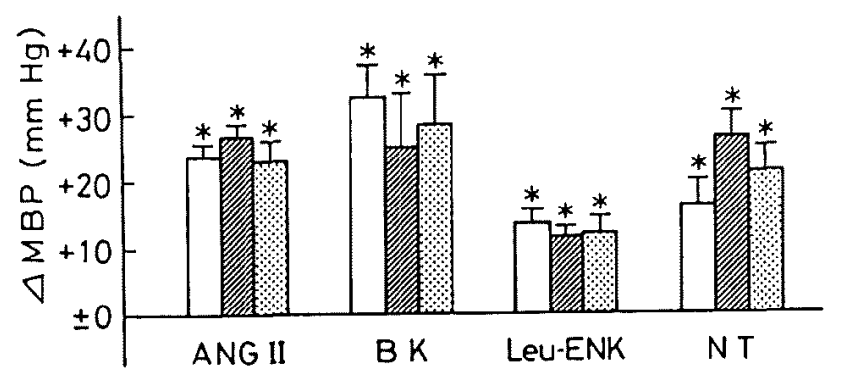

(b)

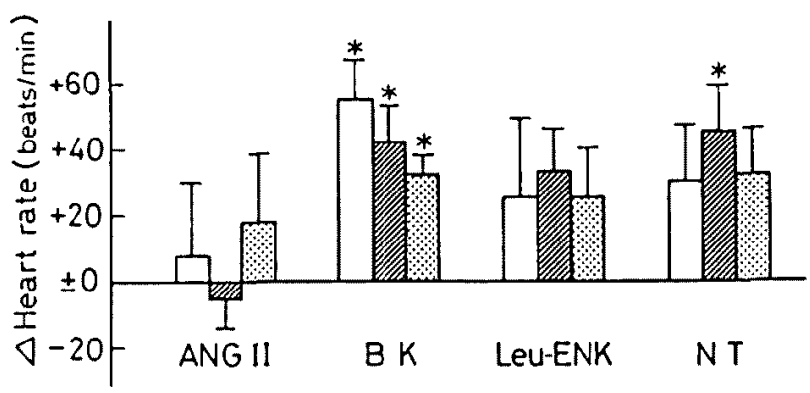

Fig. 2. (a) The maximal increase in MBP and (b) the change in heart rate after ICV injections of angiotensin II, bradykinin, leucine-enkephalin and

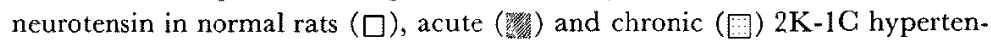
sive rats. Asterisks indicate significant differences from pretreatment values $(\mathrm{p}<0.05)$.

served only at $5 \mathrm{~min}$ and the PRA value was $71.3 \pm 5.9 \%$ of the pretreatment value.

ICV injection of Leu-ENK produced significant incrcases in PRA at 5 min in normal rats and in acute and chronic $2 \mathrm{~K}-1 \mathrm{C}$ hypertensive rats; PRA values were $141.0 \pm 11.6 \%, 123.0 \pm 6.0 \%$ and $123.3 \pm 5.7 \%$ of the pretreatment values, respectively. In acute and chronic $2 \mathrm{~K}-1 \mathrm{C}$ hypertensive rats PRA values at 30 min were significantly decreased to $71.9 \pm 2.7 \%$ and $85.3 \pm$ $3.0 \%$ of pretreatment values, respectively.

After ICV injection of NT, PRA was significantly decreased at 5 min in normal rats. In both acute and chronic $2 \mathrm{~K}-1 \mathrm{C}$ hypertensive rats, ICV injection of NT did not produce a significant change in PRA. The changes in PRA after ICV injection of these peptides are shown in Fig. 1.

\section{Blood pressure and heart rate after ICV injection}

ICV injection of artificial cerebrospinal fluid had no influence on either blood pressure or heart rate. ICV injection of ANG II, BK, Leu-ENK 
and NT all produced pressor responses in normal rats and in $2 \mathrm{~K}-1 \mathrm{C}$ hypertensive rats. The magnitude of the increase in blood pressure caused by these peptides did not differ significantly among normal rats, acute and chronic $2 \mathrm{~K}-1 \mathrm{C}$ hypertensive rats. The maximal increases in MBP after ICV injection of the peptides are shown in Fig. 2(a).

Heart rate was measured at the time when the maximal pressor response was observed. Heart rate did not significantly change in any of the 3 groups after ICV injection of either ANG II or Leu-ENK. ICV injection of BK significantly increased heart rate in all 3 groups. Heart rate significantly increased after ICV injection of NT in acutc $2 \mathrm{~K}-1 \mathrm{C}$ hypertensive rats, but did not significantly change in normal rats or in chronic $2 \mathrm{~K}-1 \mathrm{C}$ hypertensive rats. The changes in heart rate after ICV injection of the peptides are shown in Fig. 2(b).

\section{Discussion}

ICV injections of ANG II, BK, Leu-ENK and NT showed pressor responses in $2 \mathrm{~K}-1 \mathrm{G}$ hypertensive as reported previously. ${ }^{16)}$ Spontaneously hypertensive rats exhibit a marked supersensitivity to the central pressor responses of angiotensin, bradykinin and enkephalins.6),23) Chronic twokidney, two clip hypertensive rats had a significantly increased pressor response after central administration of ANG II compared with normotensive rats. $^{24)}$ Our experiments showed no significant difference between normal rats and $2 \mathrm{~K}-1 \mathrm{C}$ hypertensive rats in pressor responses after ICV injection of ANG II, BK, Leu-ENK or NT.

There are at least two efferent pathways by which the central nervous system influences renin secretion. One is the sympathetic nervous system and the other involves vasopressin which exerts an inhibitory control over renin secretion. There are several reports indicating that central administration of $\mathrm{NNG}$ II, BK, Leu-ENK or NT causes sympathetic nerve activation. ${ }^{25)-28}$ ) On the other hand, it is suggested that central administration of these peptides produces vasopressin release. ${ }^{25), 29)-31)}$ The effect of central peptidergic stimulation on renin secretion may depend on the extent of sympathetic nerve activation and vasopressin release. But the possibility that the other mechanisms may exist is not excluded.

There is no report on the change in PRA following ICV injections of ANG II, BK, Leu-ENK or NT in $2 \mathrm{~K}-1 \mathrm{C}$ hypertensive rats. In this experiment, ANG II and BK significantly suppressed PRA, NT did not affect PRA and Leu-ENK produced a significant increase in PRA followed by a significant decrease in PRA. Suzuki et al' ${ }^{10)}$ reported that ICV injection of sara- 
lasin or captopril resulted in a significant decrease in blood pressure and PRA in 2K-1C hypertensive rats. These results suggested that the decrease in PRA due to the blockade of the brain renin-angiotensin system attenuated the sympathetic nerve activation. Our results suggest that the release of vasopressin caused by centrally administered ANG II probably has an advantage over the stimulation of the sympathetic nervous system with regard to renin secretion.

We have reported that $I C V$ injections of $A N G I I, B K$, Leu-ENK or NT in sodium-restricted rats whose PRA is significantly elcvated cause changes in PRA similar to those observed in normal rats. ${ }^{32}$ In conscious 2K-1G hypertensive rats with elevated PRA, central administration of these peptides caused changes in PRA which showed some differences compared with normal rats. Since pressor responses after ICV injection of these peptides were similar in normal and $2 \mathrm{~K}-1 \mathrm{C}$ hypertensive rats, these differences in $\mathrm{PRA}$ response might be due to peripheral mechanisms such as sensitivity of the kidney to sympathetic nerve activation and plasma vasopressin concentration. In $2 \mathrm{~K}-1 \mathrm{C}$ hypertensive rats, compared to normal rats, suppression in PRA by ICV injections of ANG II or NT were attenuated or abolished. But BK and Leu-ENK produced significant reductions in PRA only in $2 \mathrm{~K}-1 \mathrm{C}$ hypertensive rats. The mechanism by which the difference was caused is not clear in this experiment.

In conclusion, the results indicate that the effects of these four centrally administered peptides on blood pressure, heart rate and PRA in acute and chronic 2K-1C hypertensive rats were not essentially different from those in normal rats, though the effect of BK on PRA in $2 \mathrm{~K}-1 \mathrm{C}$ hypertensive rats was different from that in normal rats.

\section{References}

1. Fuxe $K$, Ganten D, Hokfelt $T$, Bolme $P$ : Immunohistochemical evidence for the existence of angiotensin II containing nerve terminals in the brain and spinal cord of the rat. Ncurosci Lett 2: 229, 1976

2. Corrêa FMA, Innis RB, Uhl GR, Snyder SH: Bradykinin-like immunoreactive neuronal systems localized histochemically in rat brain. Proc Nat Acad Sci USA 76: 1489, 1979

3. Simantov R, Kuhar MJ, Uhl GR, Snyder SH: Opioid peptide enkephalin: immunohistochemical mapping in rat central nervous system. Proc Nat Acad Sci USA 74: 2167, 1977

4. Carraway $\mathrm{R}$, Leeman $\mathrm{SE}$ : Characterization of radioimmunoassayable neurotensin in the rat: its differential distribution in the central nervous system, small intestine and stomach. J Biol Chem 251: 7045, 1976

5. Palkovits $\mathbf{M}$ : Neuropeptides and biogenic amines in central cardiovascular control mechanisms. in Central Nervous System Mechanisms in Hypertension, ed by Buckley JP, Ferrario CM, Raven Press, New York, p 73, 1981

6. Ganten D, Unger Th, Rockhold R, Schaz K, Speck G: Central peptidergic stimulation: 
its possible contribution to blood pressure regulation. in Radioimmunoassay of Drug and Hormones in Cardiovascular Medicine, ed by Albertini A, Da Prada M, Peskar BA, Elsevier, Amsterdam, p 33, 1979

7. Davis JO: The pathogenesis of chronic renovascular hypertension. Circ Res 40: 439, 1977

8. Kubo T, Hashimoto M, Ohashi T: Effects of intraventricular and intraspinal 6-hydroxydopamine on blood pressure of renal hypertensive rats. Arch Int Pharmacodyn 234: 270, 1978

9. Mann JFE, Phillips MI, Dietz R, Haebara H, Ganten D: Effects of central and peripheral angiotensin blockade in hypertensive rats. Am J Physiol 234: H629, 1978

10. Suzuki H, Kondo $\mathrm{K}$, Handa $\mathrm{M}$, Saruta $\mathrm{T}$ : Role of the brain isorenin-angiotensin system in experimental hypertension in rats. Clin Sci $61: 175,1981$

11. Buggy J, Fink GD, Haywlood JR, Johnson AK, Brody MJ: Interruption of the maintenance phase of established hypertension by ablation of the anteroventral third ventricle (AV3V) in rats. Clin Exp Hypertens 1: 337, 1978

12. Haywood JR, Fink GD, Buggy J, Boutelle S, Johnson AK, Brody MJ: Prevention of twokidney, one clip renal hypertension in rat by ablation of AV3V tissue. Am J Physiol 245: H683, 1983

13. Kokubu $\mathrm{T}$, Hashimoto $\mathrm{H}$, Hiwada $\mathrm{K}$ : Effect of clonidine on blood pressure in chronic onekidney, one clip and two-kidney, one clip hypertensive rats. Chest 83 (Suppl): 359, 1983

14. Ueda $\mathrm{H}$, Yasuda $H$, Takabatake $Y$, lizuka M, Ihori M, Yamamoto $M$, Sakamoto $Y$ : Increased renin release evoked by mesencephalic stimulation in the dog. Jpn Heart J 8: 498, 1967

15. Richardson D, Stella A, Leonetti G, Bartorelli A, Zanchetti A: Mechanisms of renal release of renin by electrical stimulation of the brainstem in the cat. Circ Res 34: 425, 1975

16. Iwata $\mathrm{T}$, Hashimoto $\mathrm{H}$, Hiwada $\mathrm{K}$, Kokubu $\mathrm{T}$ : Changes of plasma renin activity by intracerebroventricular administration of biological active peptides in conscious rats. Clin Exp Hypertens A6: 1055, 1984

17. Eriksson L, Fyhrquist F: Plasma renin activity following central infusion of angiotensin II and altered CSF sodium concentration in the conscious goat. Acta Physiol Scand 98: 209, 1976

18. Malayan SA, Keil LC, Ramsay DJ, Reid IA: Mechanism of suppression of plasma renin activity by centrally administered angiotensin II. Endocrinology 104: 672, 1979

19. Kapsha JM, Keil LC, Klase PA, Severs WB: Centrally mediated hydration effects of angiotensin in various states of sodium balance. Pharmacology 18: 25, 1979

20. Cantalamessa F, de Caro G, Massi M, Micossi LG: Stimulation of drinking behaviour and of renin release induced by intracerebroventricular injections of D-ALA ${ }^{2}$, D-LEU ${ }^{5}$-enkephalin to rats. Pharmacol Res Comm 14: 141, 1982

21. Hashimoto $\mathbf{H}$, Hiwada $\mathbf{K}, \mathbf{K o k u b u} \mathrm{T}$ : Different mechanisms maintaining high blood pressure in chronic one-kidney, one-clip, and two-kidney, one-clip hypertensive rats. Clin Exp Hypertens A5: 429, 1983

22. Poulsen K, Jørgensen J: An easy radioimmunological microassay of renin activity, concentration and substrate in human and animal plasma and tissues based on angiotensin I trapping by antibody. J Clin Endocrinol Metab 39: 816, 1974

23. Unger Th, Rockhold RW, Yukimura T, Rettig R, Rascher W, Ganten D: Role of kinins and substance $P$ in the central blood pressure regulation of normotensive and spontaneously hypertensive rats. in Central Nervous System Mechanisms in Hypertension, ed by Buckley JP, Ferrario CM, Raven Press, New York, p 115, 1981

24. Schoelkens BA, Jung W, Steinbach $R$ : Blood pressure responsc to ccntral injection of angiotensin $I I$ and 8-C-phenylglycine analogue of angiotensin II in rats with experimental hypertension. Clin Sci Mol Med 51(Suppl 3): 403s, 1976

25. Severs WB, Daniel-Severs AE: Effects of angiotensin on the central nervous system. Pharmacol Rev 25: 415, 1973

26. Lambcrt GA, Lang WJ: The effects of bradykinin and eledoisin injected into the cerebral 
ventricle of conscious rats. Eur J Pharmacol 9: 383, 1970

27. Simon W, Schaz K, Ganten U, Stock G, Schlor KH, Ganten D: Effects of enkephalins of arterial blood pressure are reduced by propranolol. Clin Sci Mol Med 55: 237s, 1978

28. Sumners C, Phillips MI, Richards EM: Central pressor action of neurotensin in conscious rats. Hypertension 4: 888, 1982

29. Hoffman WE, Schmid PG: Separation of pressor and antidiuretic effects of intraventricular bradykinin. Neuropharmacology 17: 999, 1978

30. Bisset GW, Chowdrey HS, Feldberg W: Release of vasopressin by enkephalin. Br J Pharmacol 62: 370, 1978

31. Skowsky R, Smith P, Swan L: The effects of enkephalins, substance P, and neurotensin on arginine vasopressin (AVP) release in the unanesthetized cat. Clin Res 26: 108A, 1978

32. Iwata T, Hiwada K, Murakami E, Kokubu T: Effects of intracerebroventricular administration of biological active peptides on plasma renin activity in conscious rats. Clin Exp Hypertens A6: 1787,1984 